\title{
Anaplastic Lymphoma Kinase Positive Large B-cell Lymphoma Mimicking Metastatic Carcinoma of the Cervical Lymph Node from an Unknown Primary Lesion
}

\author{
Sang Woo Kim ${ }^{1}$ D, Kyuho Lee ${ }^{2}$, Bo Hae Kim ${ }^{1,3}$, and Eo Jin Kim² ${ }^{2}$ \\ ${ }^{I}$ Departments of Otorhinolaryngology-Head and Neck Surgery, ${ }^{2}$ Pathology, Dongguk University Ilsan Hospital, College of Medicine, \\ Dongguk University, Goyang; and ${ }^{3}$ Sensory Organ Research Institute, College of Medicine, Dongguk University, Gyeongju, Korea
}

\author{
원발부위 불명 전이암종과 유사한 병리학적 소견을 보이는 \\ Anaplastic Lymphoma Kinase 양성 B형 대세포 림프종 \\ 김상우 $^{1} \cdot$ 이규호 ${ }^{2} \cdot$ 김보해 $^{1,3} \cdot$ 김어진 $^{2}$ \\ 동국대학교 의과대학 일산병원 이비인후-두경부외과학교실, ${ }^{1}$ 병리학교실, ${ }^{2}$ 동국대학교 의과대학 감각기관연구소 ${ }^{3}$
}

\author{
Received August 7, 2020 \\ Revised September 29, 2020 \\ Accepted October 29, 2020 \\ Address for correspondence \\ Bo Hae Kim, MD, PhD \\ Department of Otorhinolaryngology- \\ Head and Neck Surgery, \\ Dongguk University \\ College of Medicine, \\ Dongguk University Ilsan Hospital, \\ 27 Dongguk-ro, Ilsandong-gu, \\ Goyang 10326, Korea \\ Tel $+82-31-961-7438$ \\ Fax +82-31-961-7437 \\ E-mail bohae111@naver.com \\ Eo Jin Kim MD, PhD \\ Department of Pathology, \\ Dongguk University Ilsan Hospital, \\ 27 Dongguk-ro, Ilsandong-gu, \\ Goyang 10326, Korea \\ Tel +82-31-961-7930 \\ Fax +82-31-961-7939 \\ E-mail pathejk@hanmail.net
}

Anaplastic lymphoma kinase positive large B-cell lymphoma (ALK+LBCL) is a rare subtype of B-cell lymphoma with aggressive features and a poor prognosis. The rarity of this disease and similarity of microscopic features with undifferentiated epithelial neoplasm disturb the provision of proper treatment. A 57-year-old male presented with a rapidly growing and painless mass on the left side of the neck. Metastatic carcinoma of an unknown primary (CUP) lesion was initially suspected based on the pathologic results obtained from a core needle biopsy, but it was finally diagnosed as ALK+LBCL after a modified radical neck dissection. We herein report a case of ALK+LBCL mimicking CUP with a literature review.

Korean J Otorhinolaryngol-Head Neck Surg 2021;64(10):760-5

Keywords Anaplastic lymphoma kinase; B-cell lymphoma;

Unknown primary neoplasm.

\section{Introduction}

Anaplastic lymphoma kinase-positive large B-cell lymphoma $(\mathrm{ALK}+\mathrm{LBCL})$ is a rare subtype of $\mathrm{B}$-cell origin lym-

This is an Open Access article distributed under the terms of the Creative Commons Attribution Non-Commercial License (https://creativecommons.org/licenses/by-nc/4.0) which permits unrestricted non-commercial use, distribution, and reproduction in any medium, provided the original work is properly cited. phoma encompassing less than $1 \%$ of all diffuse large B-cell lymphomas (DLBCLs). ${ }^{1)}$ Since ALK+LBCL has clinical, pathological, immunohistochemical (IHC), and molecular characteristics that are distinct from typical DLBCL, it has been classified by the World Health Organization as a single entity. Although the excision of suspicious lymph nodes (LNs) has conventionally been used for the definitive diagnosis of lym- 
phoma because this method can obtain sufficient specimens for additional immunostaining, a core needle biopsy (CNB) can often diagnose lymphoma and even identify sub-classifications of the disease. ${ }^{2)}$ We report a case of ALK+LBCL that had been suspected to be metastatic carcinoma of an unknown primary (CUP) lesion according to the pathologic results obtained from a CNB.

\section{Case}

A 57-year-old male presented to the outpatient clinic with a rapidly growing and painless mass on the left side of the neck for the past two weeks. Other symptoms, such as fever, weight loss, dysphagia, and hoarseness, were absent. A round and mobile mass (measuring about $2 \times 3 \mathrm{~cm}$ ) was palpated at the middle portion of the left neck, and the overlying skin was intact without any sign of infection. He was an ex-smoker with a history of 40 packs a year, and he had no underlying disease. There were no other palpable or visible lesions in the oral cavity or neck, and no abnormal findings were identified on endoscopic examination.

Under suspicion of a metastatic LN or lymphoma, a neck contrast computed tomography (CT) scan was performed. Although no suspicious lesion was identified as the primary tumor, two homogenous and well-enhanced LNs with a maximal diameter of about $2 \times 3 \mathrm{~cm}$ were found in the left neck without necrosis (level III) (Fig. 1A). Ultrasonography (US) revealed two hypoechoic LNs with peripheral vascularity and the loss of hilum (Fig. 1B). A CNB was simultaneously performed along with US evaluation. In the CNB specimen stained with hematoxylin and eosin (H\&E), poorly differentiated cells formed loosely cohesive clusters and nests (Fig. 2A). Although
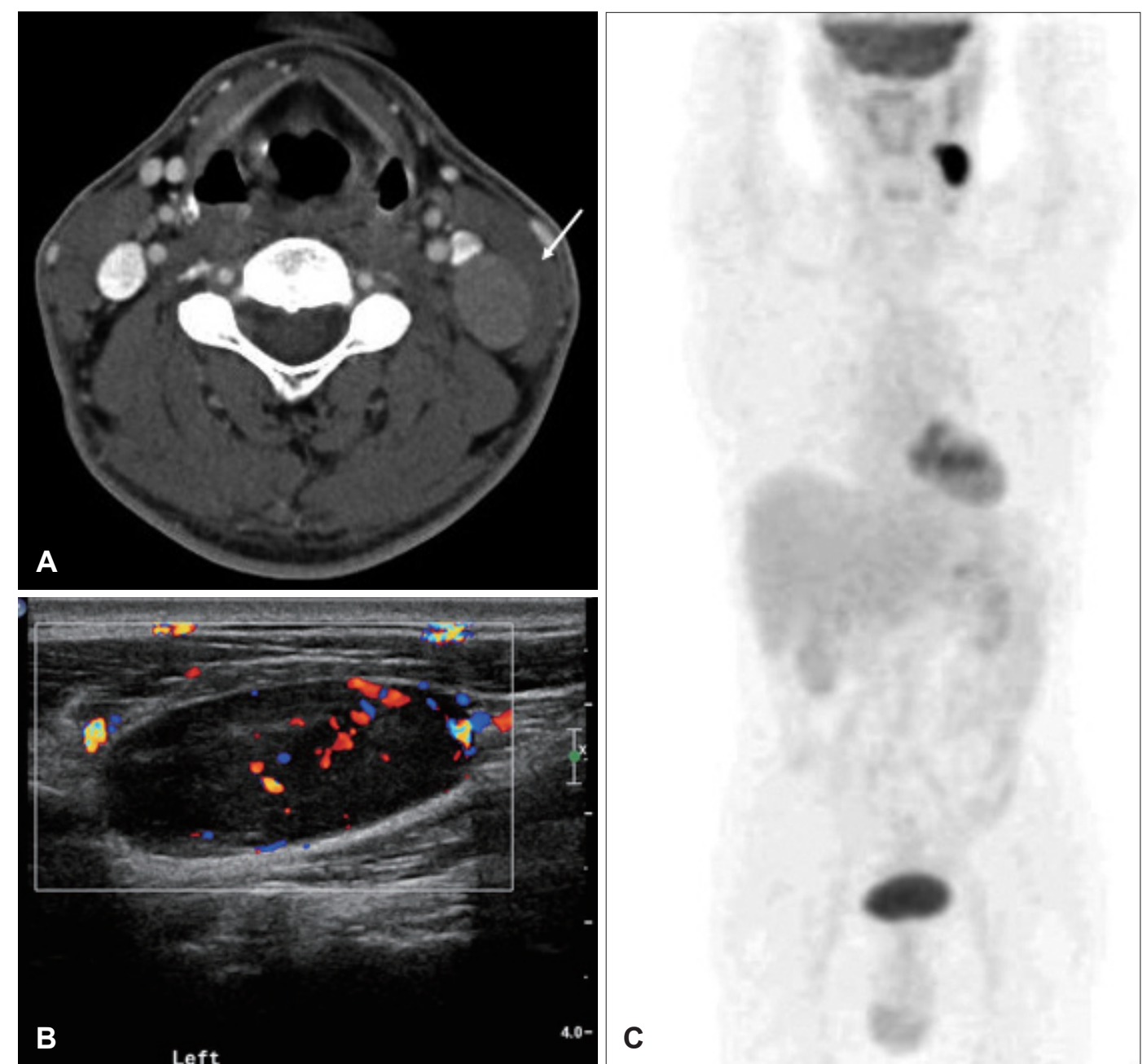

Fig. 1. Contrast neck CT shows two homogenous and well-enhanced LNs with a maximal diameter of about $2 \times 3 \mathrm{~cm}$ and the absence of internal necrosis in the level neck level III (arrow) (A). Ultrasonography revealed two hypoechoic LNs with peripheral vascularity and the loss of hilum (B). Abnormal uptake on 18-fluorodeoxyglucose PET/CT was only identified in the cervical LNs of level III $\left(S U V_{\text {max }}=2.07\right)$ (C). LNs: lymph nodes, SUV max $_{\text {: }}$ maximum standardized uptake volume. 
epithelial membrane antigen (EMA), another epithelial marker, was positive upon IHC staining, T cell (CD3), B cell (CD20), and epithelial maker, pan-cytokeratin (pan-CK) were negative upon IHC staining (Fig. 2B and C). Referring to the EMA-positive staining, the lesion was suspected to be poorly differentiated carcinoma. Additionally, IHC for PAX8, calcitonin, thyroglobulin, p16, p53, and Epstein-Barr virus were performed in accordance with recommendations in the National Comprehensive Cancer Network (NCCN) guidelines for CUP, and only IHC for p16 was positive (Fig. 2D).

No abnormal LN enlargement or suspicious primary lesions were determined on the contrast-enhanced chest, pelvic, or abdominal CT, and esophagogastroduodenoscopy also showed normal findings. However, an abnormal uptake on 18-fluorodeoxyglucose-positron emission tomography/CT (18-FDG $\mathrm{PET} / \mathrm{CT}$ ) was identified in the cervical LNs of level III (maximum standardized uptake volume, $\mathrm{SUV}_{\max }=2.07$ ) (Fig. 1C).

We planned a suspension examination of the upper aerodigestive tract followed by ipsilateral tonsillectomy and left modified radical neck dissection (MRND) under suspicion of oropharyngeal cancer from the positive p16 finding in the cervical LNs. Upon suspension of the examination, no lesion was suspected as a primary lesion despite multiple biopsies of interest confirmed by frozen-section pathology. Therefore, ipsilateral tonsillectomy and MRND were completed. Poorly differentiated cells formed relatively loose cohesive clusters and nests on H\&E staining (Fig. 3A), consistent with the findings of the specimen obtained from the CNB. However, IHC for ALK, MUM1, and CD138 showed positive findings, which confirmed the diagnosis as ALK-positive lymphoma (Fig. 3BD). Immunoglobulin heavy chain $(\operatorname{IgH})$ gene rearrangement and T-cell receptor (TCR) gene rearrangement studies using BIOMED-2 Multiplex-PCR assay protocols to determine the lymphoma origin cell revealed that a weak clonal band was observed only in the $\mathrm{IgH}$ gene-rearrangement study. Since the separated signal of ALK was found in 35 of the 50 nuclei scored, which indicates translocation of the $A L K$ gene (2p23) on fluorescence in situ hybridization (FISH), ALK+LBCL was finally confirmed. As the bone-marrow biopsy revealed no evidence of lymphoma involvement, chemotherapy for lymphoma using the cyclophosphamide, doxorubicin, vincristine, and prednisolone (CHOP) regimen was planned as conventional treatment of DLBCL two weeks after surgery. ${ }^{1,3)}$
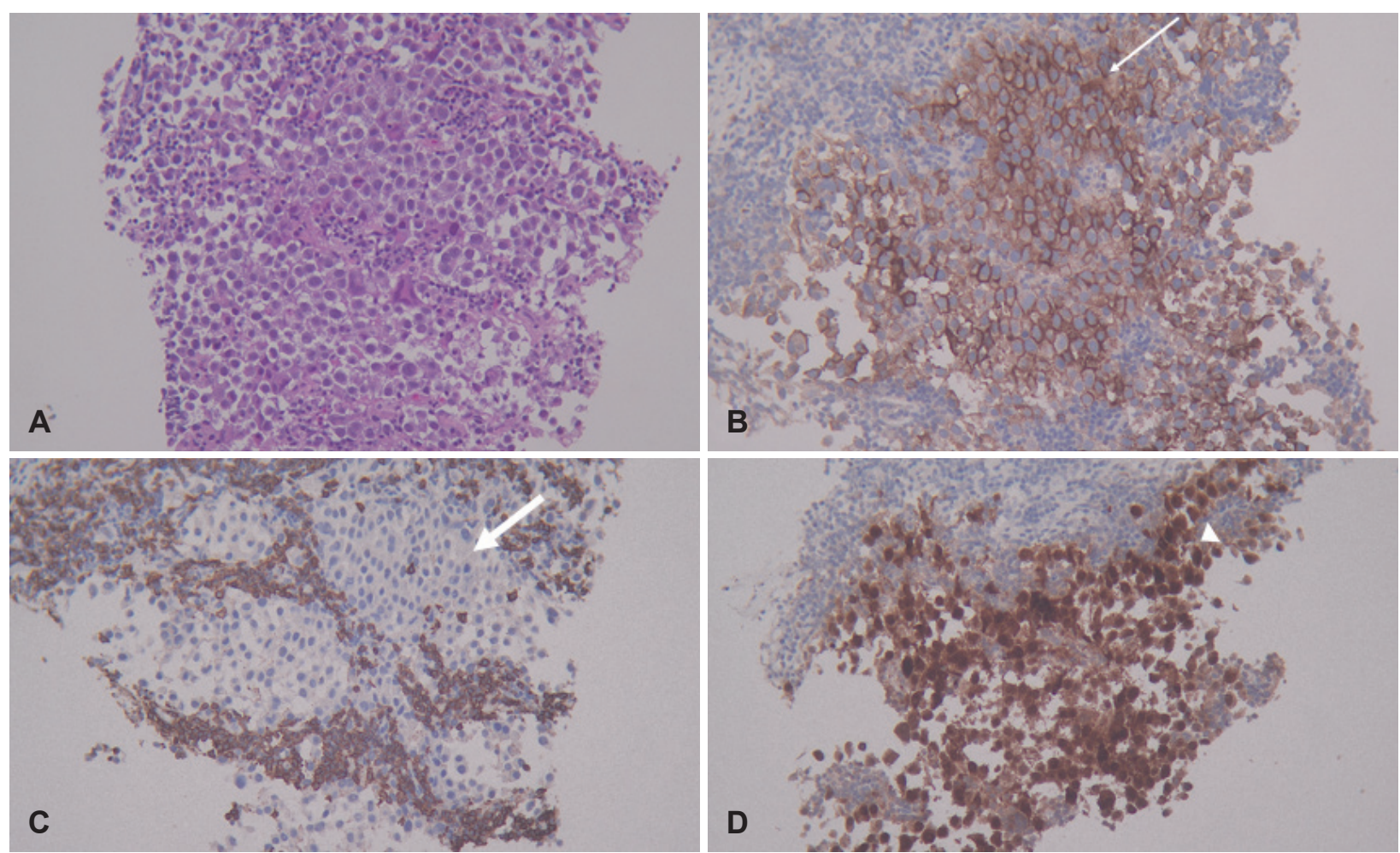

Fig. 2. Core needle biopsy revealed microscopically, monomorphic large loosely cohesive cells infiltrating the lymph node [hematoxylin and eosin $(H \& E)$ staining, $\times 200$ ] (A). Immunohistochemistry staining was positive for epithelial membrane antigen (epithelial cell marker) (arrow) (B), negative for CD20 (B-cell marker) (arrow) (C), and positive for p16 (arrowhead) (magnification $\times 200)(D)$. 

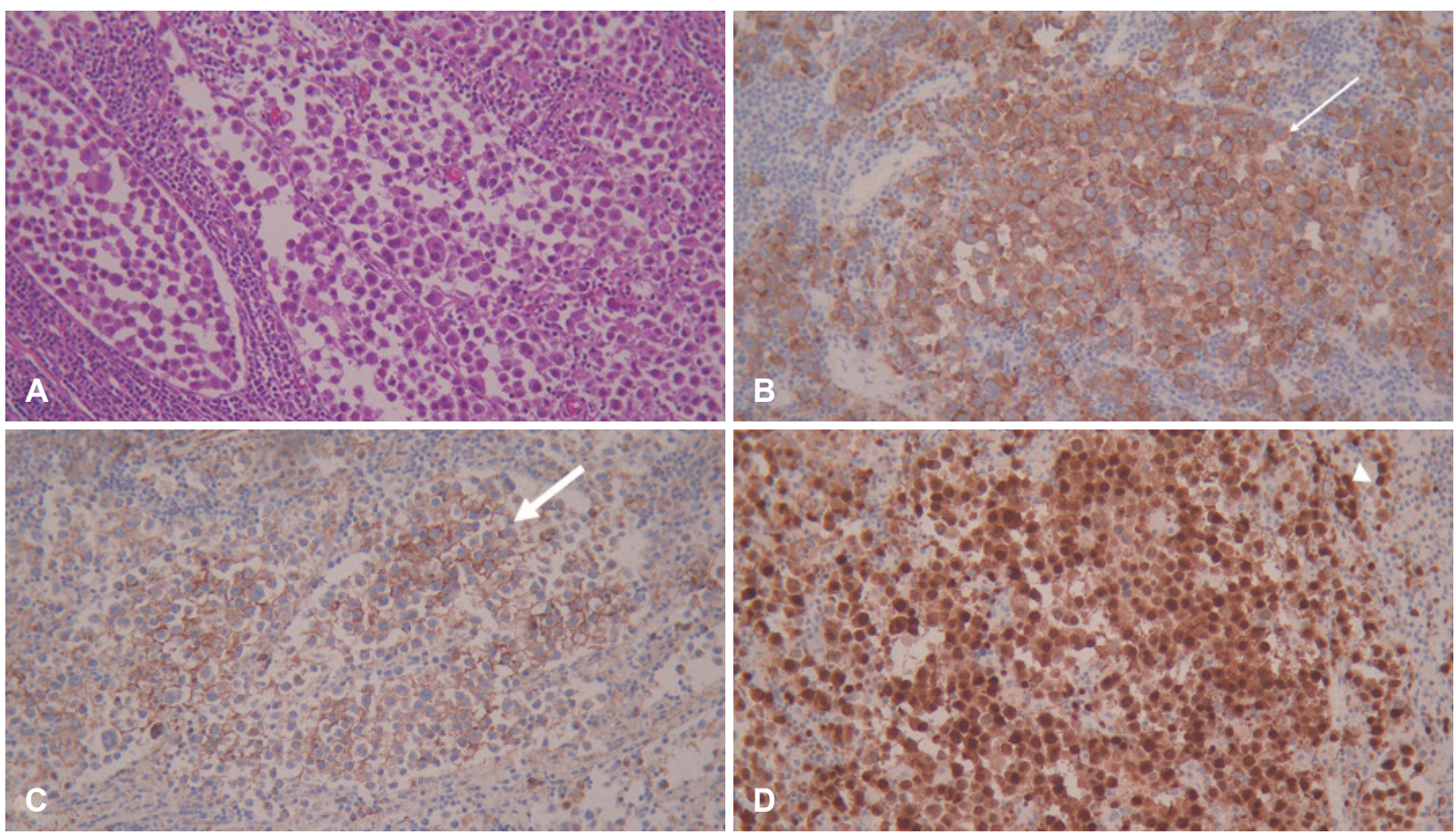

Fig. 3. Microscopic examination of the excised lymph node revealed infiltrates composed of monomorphic large cells with a diffuse or sinusoidal growth pattern [hematoxylin and eosin $(H \& E)$ staining, $\times 200](A)$. Upon immunohistochemistry staining, the cells stained positively for anaplastic lymphoma kinase (arrow) (B), CD138 (plasma cell marker) (arrow) (C), and MUM1 (plasma cell marker) (arrowhead) (magnification $\times 200)(D)$.

\section{Discussion}

ALK+LBCL is a lymphoma originating from B-cells with aggressive features and a poor prognosis. The diagnosis of $\mathrm{ALK}+\mathrm{LBCL}$ is difficult owing to its rarity, unique morphologic characteristics, and unusual immunophenotypic features that greatly overlap with those other hematologic and nonhematologic neoplasms. In particular, the lack of expression of B- and T-cell markers can hinder the diagnosis.

The $A L K$ gene was initially reported to be involved in cases of anaplastic large-cell lymphoma (ALCL), which originates from T-cells. ALCL occurs as a result of the production of nucleophosmin (NPM)-ALK fusion proteins, which lead to a DNA damage-response activation, which explains how the NPM-ALK fusion protein causes lymphoma. ${ }^{4,5)}$ Meanwhile, $\mathrm{ALK}+\mathrm{LBCL}$ originates from B-cells and the majority of ALK+ LBCL cases harbor $t(2 ; 17)(\mathrm{p} 23 ; \mathrm{q} 23)$, with fusion of the Clathrin gene (CLTC) on chromosome 17q23 with the $A L K$ gene on chromosome 2p23. ${ }^{1)}$ Although the pathogenesis of lymphoma through the CLTC-ALK fusion protein has not yet been demonstrated in ALK+LBCL, this protein is also suggested to cause DNA damage.

The differential diagnosis of lymphoma and metastatic car- cinoma is critical to ensure appropriate intervention for diagnosis and treatment. Previous studies have been conducted to investigate the clinical manifestation and radiologic findings, providing clues for differential diagnosis between two diseases. ${ }^{6-8)}$ Strassen, et al. ${ }^{6)}$ suggested that demographics such as an age of younger than 53 years, female sex, the absence of a history of smoking, and the presence of B-symptoms suggest a high possibility of lymphomatous disease such as lymphoma, sarcoma, tuberculosis, and reactive inflammation. However, the subject of this report was a 57-year-old male patient with a history of smoking without B-symptoms. Therefore, the algorithm of previous studies is not suitable in this case. The characteristics revealed from radiologic testing also provide clues for a differential diagnosis. The absence of internal necrosis in the $\mathrm{LN}$ is one of the findings suggesting lymphoma, similar to as seen among the CT findings of this case. ${ }^{\text {?) }}$ However, an uncertain string-of-bead confirmation (more than three adjacent LNs in one neck node level), peripheral vascularity on US, and relatively low SUV on 18-FDG PET/CT, despite more often being seen in correlation with metastatic carcinoma, were observed in this subject. ${ }^{8)}$ Taken together, the radiologic findings provided insufficient clues for the diagnosis of lymphoma in this subject, leading to difficulty with 
establishing the diagnosis.

Although IHC for ALK protein is the most useful diagnostic tool for the diagnosis of ALK-positive lymphoma, this staining has not been routinely conducted owing to the rarity of the disease. In addition, the microscopic features of undifferentiated cells forming cohesive nests, which is one of the pathologic characteristics of ALK+LBCL, and the unusual IHC findings of the lack of expression of B- and T-cell markers in spite of the reactivity for epithelial markers (EMAs) have distinct similarities with epithelial neoplasms. ${ }^{1,910)}$ Therefore, ALK+LBCL frequently mimics CUP, as was true in both this case and previous reports, and patients have been subjected to more extensive intervention than a single $\mathrm{LN}$ excision for biopsy, which was followed by chemotherapy as scheduled. ${ }^{3,11)}$ Thus, physicians should be aware of the possibility of unusual lymphoma subtypes before surgical intervention, even in cases that lack both B-cell (CD20, CD79a, and PAX5) and T-cell (CD3, CD4) marker expression. In addition, since positive results for plasma cell markers such as CD138 and MUM1 are frequently present in ALK+LBCL, IHC staining for these markers is also helpful in making the diagnosis of lymphoma. ${ }^{1)}$ Thus, a detailed pathology review, discussion of the results between the physician and pathologist, and additional specific IHC staining may help to minimize the risk of extensive surgical intervention in cases of ALK+LBCL mimicking carcinoma.

The overexpression of p16 in cancers is a result of the inactivation of retinoblastoma $(\mathrm{Rb})$ protein and increased E7 oncoprotein induced by human papillomavirus (HPV). It has been suggested that p16 transcription may be directly induced by transcription factor E2F, which is released from inactivated $\mathrm{Rb}$ protein after binding with HPV E7. ${ }^{12)}$ Of the known head and neck cancers, the most relevant location of HPV infection is the oropharynx, especially the tonsils, with about $40 \%$ to $60 \%$ of oropharyngeal cancers being correlated with HPV infection. ${ }^{12,13)}$ The overexpression of p16 in metastatic LNs has been used to identify hidden malignancies in the oropharynx when the primary malignancy site is unclear and about $50 \%$ of hidden primary malignancies are found in the oropharynx in patients with p16-positive CUP. ${ }^{12)}$ However, it should be kept in mind that 16 overexpression commonly accompanies more than $40 \%$ of the DLBCLs. ${ }^{14)}$ Although the mechanism of 16 overexpression induced by $A L K$ gene activation has not been well-demonstrated to date, the $A L K$ gene is known to significantly contribute to the overexpression of $\mathrm{p} 16 .^{14,15)}$ Thus, we should remain aware that p16 overexpression can be present not only in HPV-related carcinoma but also in ALK+LBCL.

Interestingly, ALK+ALCL patients have a better response to conventional regimens than those with other T-cell lymphomas, but patients with ALK+LBCL exhibit poor responses to conventional chemotherapy for DLBCL, which is CHOP regimen, experiencing a 34\% five-year overall-survival rate and a median survival time of 1.83 years. ${ }^{1)}$ Therefore, alternative regimens have been introduced to improve the results of chemotherapy by adding etoposide, conducting dose adjustment of prednisolone and doxorubicin, or including dexamethasone instead of prednisolone. In addition, the potential use of ALK inhibitors has been proposed. However, the efficacies of these alternative regimens have not been proven yet. ${ }^{1)}$ Therefore, further studies are needed that focus on why therapeutic reactions to conventional regimens vary depending on the origin of cells in ALK+lymphoma, while studies assessing the use of alternative regimens to discern potential better therapeutic responses are required.

In conclusion, the diagnosis of ALK+LBCL is difficult to confirm owing to its rarity and pathologic features that mimic epithelial neoplasms without either B cell and or T cell marker expression. In addition, since this disease often expresses p16 protein, which provides a clue suggesting the oropharynx as the hidden primary site of CUP, we should be aware of ALK+LBCL in cases suspected as CUP.

\section{Acknowledgments}

None.

\section{Author Contribution}

Conceptualization: Bo Hae Kim, Eo Jin Kim. Data curation: Sang Woo Kim, Kyuho Lee. Formal analysis: Bo Hae Kim, Eo Jin Kim. Methodology: Bo Hae Kim. Supervision: Bo Hae Kim, Eo Jin Kim. Visualization: Sang Woo Kim. Writing — original draft: Sang Woo Kim. Writing — review \& editing: Kyuho Lee, Bo Hae Kim, Eo Jin Kim.

\section{ORCIDs}

Bo Hae Kim

https://orcid.org/0000-0002-4645-0678

Eo Jin Kim https://orcid.org/0000-0002-6570-264X

Sang Woo Kim https://orcid.org/0000-0003-0011-0552

\section{REFERENCES}

1) Pan Z, Hu S, Li M, Zhou Y, Kim YS, Reddy V, et al. ALK-positive large B-cell lymphoma: A clinicopathologic study of 26 cases with review of additional 108 cases in the literature. Am J Surg Pathol 2017;41(1):25-38.

2) Lachar WA, Shahab I, Saad AJ. Accuracy and cost-effectiveness of core needle biopsy in the evaluation of suspected lymphoma: A study of 101 cases. Arch Pathol Lab Med 2007;131(7):1033-9.

3) Lekuya HM, Kalanzi EW, Mbine R, Omoding A, Rosenwald A, Lemperle G, et al. A supraclavicular ALK-positive anaplastic 
large-cell lymphoma initially misdiagnosed and yet successfully treated with wide excision and adjuvant chemotherapy: A case report. SN Compr Clin Med 2019;1:716-25.

4) Lobello C, Bikos V, Janikova A, Pospisilova S. The role of oncogenic tyrosine kinase NPM-ALK in genomic instability. Cancers (Basel) 2018;10(3):64.

5) Ducray SP, Natarajan K, Garland GD, Turner SD, Egger G. The transcriptional roles of ALK fusion proteins in tumorigenesis. Cancers (Basel) 2019;11(8):1074.

6) Strassen U, Geisweid C, Hofauer B, Knopf A. Sonographic differentiation between lymphatic and metastatic diseases in cervical lymphadenopathy. Laryngoscope 2018;128(4):859-63.

7) Lee YY, Van Tassel P, Nauert C, North LB, Jing BS. Lymphomas of the head and neck: CT findings at initial presentation. AJR Am J Roentgenol 1987;149(3):575-81.

8) Yu C, Xia X, Qin C, Sun X, Zhang Y, Lan X. Is SUVmax helpful in the differential diagnosis of enlarged mediastinal lymph nodes? A pilot study. Contrast Media Mol Imaging 2018;2018:3417190.

9) Choung HS, Kim HJ, Kim WS, Kim K, Kim SH. [Cytomorphology and molecular characterization of CLTC-ALK rearrangement in 2 cases of ALK-positive diffuse large B-cell lymphoma with extensive bone marrow involvement]. Korean J Lab Med 2008;28(2):89-94.
10) Morris SW, Kirstein MN, Valentine MB, Dittmer K, Shapiro DN, Look AT, et al. Fusion of a kinase gene, ALK, to a nucleolar protein gene, NPM, in non-Hodgkin's lymphoma. Science 1995;267(5196): 316-7.

11) Hudacko R, Rapkiewicz A, Berman RS, Simsir A. ALK-negative anaplastic large cell lymphoma mimicking a soft tissue sarcoma. J Cytol 2011;28(4):230-3.

12) Park GC, Lee M, Roh JL, Yu MS, Choi SH, Nam SY, et al. Human papillomavirus and p16 detection in cervical lymph node metastases from an unknown primary tumor. Oral Oncol 2012;48(12):1250-6.

13) Geißler C, Tahtali A, Diensthuber M, Gassner D, Stöver T, Wagenblast J. The role of $\mathrm{p} 16$ expression as a predictive marker in HPV-positive oral SCCHN--a retrospective single-center study. Anticancer Res 2013;33(3):913-6.

14) Lee ES, Kim LH, Abdullah WA, Peh SC. Expression and alteration of p16 in diffuse large B cell lymphoma. Pathobiology 2010;77(2): 96-105.

15) Vega F, Chang CC, Medeiros LJ, Udden MM, Cho-Vega JH, Lau $\mathrm{CC}$, et al. Plasmablastic lymphomas and plasmablastic plasma cell myelomas have nearly identical immunophenotypic profiles. Mod Pathol 2005;18(6):806-15. 